\title{
THE CASE METHOD AS INVENTED TRADITION: REVISITING HARVARD'S HISTORY TO REORIENT MANAGEMENT EDUCATION
}

\author{
TODD BRIDGMAN \\ School of Management \\ Victoria University of Wellington, New Zealand \\ STEPHEN CUMMINGS \\ Victoria University of Wellington \\ COLM MCLAUGHLIN \\ University College Dublin
}

\begin{abstract}
Support for the case method reflects a conviction that business education should be training in solving business problems. However, opponents see it as contributing to a narrow, instrumental, amoral perspective on business. We revisit the emergence of the method at Harvard to think beyond this polarization for the future.

\section{INTRODUCTION}

Few would argue that Harvard Business School has been the most influential institution in the history of business education. An oft cited explanation for its continued influence has been its unwavering clarity of purpose - that the principal objective of a business education is to learn how to solve business problems and its total commitment to the case method of teaching as the means for delivering this objective. Students following the 'Harvard method' take real-life situations and through an analytical process develop a set of problem-solving recommendations.

This bias for action, the "raison d'etre of the case method" (Garvin, 2003: 62) designed to simulate the reality of corporate leadership, has been criticised for constructing mythical, heroic portrayals of leadership (Chetkovich \& Kirp, 2001); privileging senior management views (Mintzberg, 2004); leading students towards pre-determined answers (Currie \& Tempest, 2008); focusing on the solving of problems rather than the framing and definition of problems (Chia, 2005); excluding the voice of women and the poor (Kweder, 2014); and neglecting the interests and influence of other stakeholders (Bridgman, 2010). The merits and flaws of the case method have been staked out along these lines, with the positions of critics and defenders becoming increasingly entrenched. Our objective in this paper is to progress the discussion beyond the binary good/evil which enslaves contemporary debates.
\end{abstract}

\section{A CONVENTIONAL HISTORY OF THE HBS CASE METHOD}

Histories of the HBS case method (for example, Copeland, 1958; Garvin, 2003; Grandon Gill, 2011; Mesney, 2013) follow a narrow channel - starting with the business school's adaptation of the approach to legal education at Harvard. In 1870, Christopher Columbus Langdell, Dean of the Harvard Law School, felt law would be best studied through the derivation of general principles from numerous examples, so he took the radical step of refusing to give a 
lecture, instead asking a surprised student to "state the case" (Cruikshank, 1987: 74). An interested observer of the law school's progress was Edwin Gay, the first Dean of Harvard's business school established in 1908. Gay was succeeded in 1919 by law school alumnus Wallace Donham. Donham was also familiar with the case-based approach of Harvard Law School and moved quickly to develop it further at HBS, convincing marketing professor Melvin Copeland to produce a 'problem' book rather than a standard textbook (Copeland, 1958; Cruikshank, 1987).

Donham prepared a memorandum in 1920 which outlined his vision for the school: "How can we state the aims of the school? I have tried as follows: 1. We try to fit the student for business by: A. Furnishing the background of general business facts and principles necessary to a broad business point of view and to progress in business. B. giving the student training for practice in dealing with business problems. This requires practice in 1) ascertaining facts; 2) appraising and sorting facts; 3 ) stating business problems in a business way; 4) analysing business problems; 5) reaching definite conclusions; 6) presenting such conclusions orally and in writing. (Donham in Copeland, 1958: 77). Conventional historical accounts draw a straight line from this articulation of the HBS case method in 1920 to today. This history is presented as being important, since "modern cases retain the same basic features described by Donham" (Garvin, 2003: 60), but unremarkable and without hint of alternative views or any wavering from the original aims.

\section{A COUNTER HISTORY OF THE HBS CASE METHOD}

This narrative of continuity from the origins of the case method to its application in business schools today is shared by critics as well as supporters, giving legitimacy to the binary positions held by all protagonists in the debate. In reading of past events in and around HBS, we discovered there was far more contestation around the case method and what it might be than is acknowledged in its 'history'. The conventional thinking about the case method today is what Wallace Donham thought about it in 1920, but this does not reflect how his thinking was challenged and shifted through the tumultuous period of the 1920s and 1930s, when the United States was gripped by social and economic crisis - conditions not dissimilar, it could be argued, to the challenges of today.

We contend that the case method of teaching, as understood by both its advocates and its critics, is an "invented tradition". According to Hobsbawm and Ranger (1983), traditions which are claimed and appear to be old are often not as old as we assume, or are largely fictitious. They are often constructions of a "suitable historic past" (1983: 1). Such invented traditions have the effect of establishing social cohesion, legitimating institutions and authority relations; and inculcating beliefs and values. They also shape present and future practice by developing conventions, which become established as 'best practice' that is passed onto new practitioners. Our analysis takes a "deeper lens on time" (Wadhwani \& Bucheli, 2014: 17-8), focusing on the period between the World Wars when the case method was becoming established at HBS. We highlight three critical moments during Donham's tenure which shed new light on how the HBS case method could have been different in the past and has the potential to stimulate new thinking on how it could be different in the future.

\section{Taking the Perspective of Organised Labor}

Both mainstream and critical accounts of the HBS case method see the cultivation of a 
managerial mindset as an integral and enduring feature of its history. Whilst good managers need to be aware of the views of stakeholders, students are nevertheless required to occupy "the shoes of the managers" (Hammond, 2009: 1). Yet, an incident early in Donham's tenure as Dean, at a time when the case method was taking shape, suggests that encouraging students to take the position of organised labor was part of Donham's development plans. Donham had learnt from his time as a receiver at the Bay State Street Railway Company between 1917-19 the importance of understanding the perspective of organised labor. He had kept several thousand disgruntled streetcar workers on the job throughout the war, with the railway union giving him a silver clock in recognition of his efforts (Cruikshank, 1987). The written form that we associate with the case method today had not established itself at HBS at this time. Rather, courses could include a series of "walking cases", with local people connected with business invited in to present their 'problems' to the class, alongside faculty (including Donham himself) who would share their own experiences (Cruikshank, 1987: 71). Donham hired Robert Fechner, an influential labor leader with the International Association of American Machinists, a union affiliated to the American Federation of Labor (AFL), to offer the labor view on courses in Labor Technique and Labor Problems.

Fechner's appointment raised the ire of benefactor F. C Hood, who operated a rubber factory in Watertown, Massachusetts. Hood wrote to Donham in January 1921 with his concerns about the teaching of labor and its potential negative effect on the endowment fund. Hood noted that "Some of the boys in the Business School told me that they were saturated with the union labor standpoint" (Hood to Donham, 28 January 1921, Baker Library Historical Collection). Hood also relayed his concerns to Howard Elliott, a Harvard graduate, chief executive and endowment seeker for HBS. Elliott wrote to Donham in April 1921 asking about Fechner and questioning whether it was "a wise thing" to have him lecturing "young men of impressionable age" and "sowing the seeds of social unrest". Donham was staunch in his defence of Fechner's appointment, arguing that "what we are doing is not only dangerous but exceedingly constructive", since labor issues had been ignored previously and providing this perspective better enabled students to think critically.

The Fechner incident is mentioned in Cruikshank's history of HBS, but is missing from Copeland's later account. More significantly, Donham's openness to the voice of organised labor, based on his experiences of the railways and the rapidly shifting context of the day, is not part of the conventional story of the origins of the HBS case method.

\section{Critically Interrogating the Values Underpinning 'Rational' Managerial Actions}

Donham's 1920 memorandum outlining the case method is the epitome of a rational decision making process - identify the problems, analyse the causes and take action to resolve them. Supporters see this as a strength, while critics highlight its' failure to acknowledge the non-rational, value-laden nature of managerial decision-making. In our reading of the past, critical reflexivity was actually seen as part of its promise. A central character in this thread is Ordway Tead who taught with Donham and Fechner on the courses in Labor Technique and Labor Problems at HBS during the 1920s. Tead was also a lecturer and adjunct professor of industrial relations at Columbia University (1920-1950). He campaigned for tripartite management structures that would dilute employer power and give workers and consumers an effective voice. Tead was excited by HBS' development of the case method, describing it as "an exceedingly provocative method of instruction" (1921: 363) for requiring students' minds to be 
active, critical and creative. Tead regarded management and administration as moral arenas, involving decisions which are moral acts, because of the enormous influence that organisations have over people's lives. Therefore, any study of business and administration without an explicit consideration of values was an impoverished one: "it is important educationally to clarify the sources of authority and the moralized ways of exercising it" (1960: 8).

Like many of his contemporaries, Tead saw value in the application of psychology to industrial issues. However, he also knew that armed with this knowledge of human behaviour "exploitation of corporate groups by clever leaders" was a real possibility (1933: 4). In the second edition of his book Human Nature and Management, Tead added an appendix of questions and case problems. The objective was the "stimulation of clear thinking and cultivation of a broad, liberal, and humane attitude of attack on problems of human relations" (1933: 309). In the cases, Tead wanted to highlight both the power of industrial psychology as well as its potential for exploitation - and he made clear his position was to work against such exploitation through his teaching. While Tead was well respected and his writing was influential at this time, he appears as a marginal figure in contemporary management history. While there has been some attempt to recover Tead's contribution to management thought (O'Connor, 2001), his pedagogical writing has received little attention. Tead is not mentioned in either Cruikshank's or Copeland's histories of HBS. Our alternative history suggests his contribution could stimulate rethinking what the case method could be in the future.

\section{A Philosophically Informed, Sociological Study of Business and Society}

English philosopher Alfred North Whitehead joined Harvard's Philosophy Department in 1924 and stayed there until his retirement in 1937. Barnes et al (1994: 5) note that HBS "owes a great deal to the intellectual gifts" of Whitehead. Whitehead was a strong supporter of the business school's place in the university and its desire to be considered a profession. In a lecture given to HBS (and included as the introduction of Donham's (1931) book Business Adrift), Whitehead outlined his vision for business education, which he called "sociology in the broadest sense of the term" (xiii). Whitehead saw successful societies as being based on routine, which created stability, which in turn made foresight possible. Foresight was "a reflective power", a "survey of society from the standpoint of generality. This habit of general thought, undaunted by novelty, is the gift of philosophy" (xxvi-xxvii). Foresight enabled business students to understand and predict social change - the antithesis of short-sightedness which Whitehead saw as symptomatic of his Age. This idea of foresight extended beyond the notion of "enlightened self-interest" which had become popular during the 1920s, as capitalists such as Rockefeller responded to rising labor unrest. What Whitehead advocated was not a study of business in society, but a study of society, based on a philosophic outlook, in which business plays an important part.

In Business Adrift Donham (1931) accepted Whitehead's identification of constant change as the major threat facing Western civilization. The US' descent into economic crisis was evidence enough for Donham that this apocalyptic vision was becoming reality. Donham, while desperate to defend capitalism against the threat of the Soviet Union, admired the Soviets' emphasis on planning, even conceding that "it may turn out that from a material point of view socialism makes possible higher standards of living than capitalism" (37). Local newspaper The Harvard Crimson commented "These ideas are not new, but they have hitherto been considered radical, indeed socialistic, and it is a surprising indication of the progress of the times to hear 
them from the Dean of a Harvard graduate school" (September 21, 1932). Donham also became critical of the approach to the case method he had promoted in his 1920 memo, claiming it had led to a preoccupation with solving management problems in organisations. "We need in business and politics administrators who are able not only to handle their specialized problems well, but also to see things in wide relations and do their part in maintaining society's stability and equilibrium" (Donham, 1933: 420).

Reflecting on his tenure as Dean, Donham (1949) noted the great influence of Whitehead's philosophy of education on his own thinking. In the histories of HBS, however, Whitehead's contribution is distinctive for its selectivity. Barnes et al (1994) credit Whitehead's lasting legacy of action oriented learning, but say nothing of his view of business as a sociological study. They also make nothing of Donham's political writing. Their description of the case method is managerialist in tone, consistent with today's orthodoxy. Copeland (1958) devotes a whole chapter to Donham but makes no mention of either his friendship with Whitehead or his writing on the state of US capitalism in the 1930s. Looking again at Whitehead's views on business education could reinvigorate pedagogical debates today.

\section{RECONSTRUCTING THE PAST TO REORIENT THE FUTURE}

The dramatically shifting context of the 1920s and 1930s provided fertile ground for the germination of different ways of thinking about business education. Donham questioned the narrow, instrumental approach to a training in business administration that he articulated in his 1920 memo to faculty. However, the histories of HBS and of the case method, most of which were written after WWII, have largely forgotten these moments in favour of a smoother, more homogenous narrative. The post-war business school environment became an era of mass expansion for business education, and attention was focused not on the case method, but the need for business schools to improve their academic standing through the development of a systematic, scientific body of knowledge. Supporters of the case method were keen to distance it from science by emphasising its training function. Developments after WWII were largely technical, such as parabola-shaped classrooms and positioning lecturers below their students, rather than overlooking them from a raised platform (Barnes et al, 1994). The narrow, managerialist understanding of the case method as originally conceived by Donham in his 1920 memo fitted well with the ideological underpinnings of human relations, which had transformed the HBS curriculum. The case method was promoted as being democratic (students participate in class rather than being 'told what to think'); individual (every situation is treated differently and stereotypes and categorisations are avoided); and co-operative (students have a common goal to analyse the case and learn from each other) (Ronken, 1953).

The failure of the case method to develop a more critical orientation was a disappointment for Tead, who believed it had become an "educational gadget" (1953: 106). Business cases had become intellectual exercises with students required to find solutions according to the criteria of profit maximisation and logistic feasibility, without any scrutiny of the preconceptions and values that both teachers and students brought to these analyses. Tead concluded it was "a pity that there is no longer an Alfred North Whitehead to help lead the technicians out of the bleak wilderness of techniques discussed without benefit of some philosophy" (106).

While the conventional history of HBS does not encourage dwelling on alternative

approaches to the case method, rethinking this history could provide crucial tools for thinking 
afresh about the challenges facing business schools today, especially given the parallels in the turbulent macro-economic environment between those times and now. We could, for instance, draw on a critical history of the case method to challenge the dominance of the decision-forcing case - the structuring technique that places students in the 'shoes' of a character in the case, usually a manager, needing to make a decision to solve a business problem. We might extend the lesson of Donham's defence of the inclusion of organised labor to other stakeholders, who had less of a presence in the 1920s and 1930s, and who may be impacted by management decisions and may not share the same managerial perspective, such as non-unionised workers, particularly those marginalised in atypical and insecure employment, local communities and NGOs. Here we are not envisioning the classic 'stakeholder perspective', where students consider the interests of other stakeholders and take them into account in making a decision, but rather their perspective might be analysed as part of a deeper and more critical thinking around the impact of business on its stakeholders.

We could also draw on the contribution of Tead, who taught with Fechner and Donham on those labor courses at HBS, to consider how the case method can be deployed to stimulate critically reflexive practice (Cunliffe, 2002). Tead wanted students to understand advancements in industrial psychology but also to be aware of its exploitative effects, especially if applied instrumentally in organizations. He was advocating a study 'of' management rather than 'for' management, an aim shared by scholars of critical management studies. These issues remain as relevant today as they did 80 years ago, given what we know about exploitation of workers in MNC supply chains, the growth of zero hour contracts, which shift many of the risks in employment from the employer to the employee, exploitation of local communities and exploitation of the earth's natural resources.

Donham's friendship with Whitehead significantly shifted his thinking about business and its sociological function and led to his interventions in national political debate. It also gave him a new perspective on the limitations of the case method in its conventional form. In this spirit, the case method might be re-envisaged to elicit a deeper critique of modern day capitalism and its impact on society; that students would be challenged with deeper questions about the relationship between business and society, such as: 'do corporations have too much power and influence?', 'what role should the state play in regulating business?', or 'is contemporary capitalism part of the problem when it comes to the issues of our Age, such as climate change?'.

\section{CONCLUSION}

Our aim has been to identify a more diverse set of possibilities of what the HBS case method could be, compared with today. However, the debates involving Donham, Whitehead, Tead, Hood and Fechner were about much more than the case method - they were about the form of business education in general. Then, as now, case teaching and business pedagogy in general are connected. However, the investment in the status quo with regard to each may be narrowing the other. Harvard, and its past need not be a barrier stifling development. Rather, our limited understanding of its history is the problem. If we can better appreciate the debates we have highlighted here it may inspire us to think differently about the state of business education and the aims we are seeking to serve, as managers and educators, today and for the future.

\section{REFERENCES AVAILABLE FROM THE AUTHORS}

